\author{
Military Technical College \\ Kobry El-Kobbah, \\ Cairo, Egypt
}

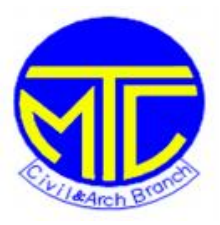

\title{
The Bio-Climatic Analysis and Thermal Performance of Residential Building in Upper Egypt A Case Study, "East El-Owauinat Region"
}

\author{
M. H. Khalil* and A. A. Gira**
}

\begin{abstract}
As a result of the change and development of Egyptian society, Egyptian government has focused its attention of comprehensive development to various directio ns. One of these attentions is housing, construction and land reclamation in Upper Egypt to go out from the narrow valley which is about 5\% of Egypt area. East El- Owauinat is one of these areas. It is an agriculture project and must be valid all the facto rs needed for sustainability. East El Owauinat region is located at $22^{\circ} 28^{`} \mathrm{~N}$ latitude and $28^{\circ} 42^{`} \mathrm{E}$ longitude. The climate of this region is caricaturized by; aridity, high summer daytime temperature, large diurnal temperature variation, low relative humidity and high solar radiation reaches to about $1000 \mathrm{~W} / \mathrm{m}^{2}$ on horizontal surface in summer seasons .

In such environments, man losses his ability to work and to contribute effectively in the development planning due to the high thermal stress affected on him. The strategy of building in this regioy to understand the needs of the people but to create an indoor environment which is suitable for healthy, and comfortable to live and work in it. Also, reduce or if possible eliminate the energy expenditure for environmental control. In order to achieve this, attention has to be focused on building design which is a function of building form, orientation, location, and materials used. This study deals with the bio-climatic analysis of East ElOwauinat region and the thermal performance of building in this region to valid the Egyptian Energy Efficiency Residential Code. The results show that, the air catcher, court and Passive cooling systems (evaporative cooling), maintained the indoor climate in the thermal huma $\mathrm{n}$ comfort zone during the hottest period under the effect of climatic conditions of East El Owauinat. Orientation, size, shape, building materials and outdoors -climatic factors influence in energy auditor of the building envelope. Also shading devices, ins ulating materials, and smart glass achieve a harmony building with environment, and save energy by about $60 \%$. Thermal insulation is needed for all exposed roofs and the required thermal resistance has a minimum R-value $\geq 2.5 \mathrm{~m}^{2} \mathrm{~K} / \mathrm{W}$. The required thermal resistance for walls must be between 0.9 and $1.3 \mathrm{~m}^{2} \mathrm{~K} / \mathrm{W}$.
\end{abstract}

\section{Key Words:}

Thermal performance, insulation, energy saving, bio-climatic analysis, building envelope

* Mervat Hassan Khalil, Assos. Prof., Building Physics Institute, Housing and Building National Research Center, Cairo, B.O. 1770, Cairo

** Amr A .Gira, Lecturer in Arch. Design and Environmental control. Department of Arch. MTC,Cairo, Egypt. 


\section{INTRODUCTION}

East El-Owauinat is a new region located in the southwestern part of Egypt at $22^{0} 28^{\wedge} \mathrm{N}$ latitude and $28^{\circ} 42^{`} \mathrm{E}$ longitude and about $365 \mathrm{Km}$ south Dakhla. It linked by paved road with Kharga, Dakhla oasis and Abu Siambel city. Also it linked by an air line from Cairo airport. The total area of it is 528 thousand acres used in the agricultural project. The area of the project is divided into 22 pieces, each area of 24 thousand acres to be reclamation and cultivation of 10 thousand acres and the rest of the safety belt underground reservoir with a total 220 thousand acres in addition to 7 thousand acre experimental farm. Agricultural Development and the National Authority for Remote Sensing assessment of environmental risks to the movement of sand dunes and faults the floor constantly and located most of the soils in the sandy soil and sandy loam, and one of the best arable land and apply the irrigation system developed in this region of both types, "irrigation sprinkler irrigation drip " by drilling wells to tap underground water storage. The crops that enjoys cultivated area of field crops, including fibers such as cotton, fodder and grain crops such as wheat, beans, soy and oil crops such as peanuts, sesame and vegetable crops and medicinal plants. In addition to horticultural crops, including dry-date and a half dry and fruits and ......etc. A Horticultural Services Unit of the Ministry of Agriculture farm animal production in association with the Australian side 5 thousand nine head extension by 3 units manufacturing feed. Also the area was suitable for breeding ostriches. Where a farm has been established by the one of the companies allotted land in the region, which is a new addition to maximize the maximum benefit from the climate and the nature and circumstances of the region. The association cooperative housing for workers in the region and the province to allocate 250 thousand square meters with a nominal price per square meter was developed division for land; ratification has been initiated in the distribution to the neighborhood association members, which will help the stability of working with families. It also ratifies the region connecting the various facilities of the credits the province. 664 wells have been drilled in the project area by the companies which enough to irrigate an area of 79,680 acres. The project aims to increase the agricultural land area of 227 thousand acres and the creation of a new urban community in agricultural and industrial integrated outside the Old Valley, as well as creating jobs to eliminate unemployment in addition to encourage investors in the field of agricultural development in the advanced system of agriculture and irrigation ${ }^{(1)}$.

Where The climate of this region is caricaturized by; aridity, high summer daytime temperature, large diurnal temperature variation, low relative humidity and high solar radiation reaches to about $1000 \mathrm{~W} / \mathrm{m}^{2}$ on horizontal surface in summer seasons. These extreme thermal environments reflected on people and their effort in development and sustainability due to the high thermal stress. So it is important to study and evaluate the effect of the external environment and the thermo physical and optical properties of the building materials on the availability of comfort for people in residential building in this region.

With the energy crisis, efforts have been motivated towards the development of new concepts for building design and urban planning to moderate the rate, direction and magnitudes of heat flow and reduce or if possible eliminate the energy expenditure for environmental control . In order to achieve this, attention has to be focused on building design to improve its thermal performance and produce indoor comfortable environmental conditions. The strategy of building in such climate dependent on controlling the indoor environment conditions to make it healthy and comfortable to achieve a large contribution of people in development planning. Where, Building envelope regards as the main construction element which has an important role in the thermal performance of unconditioned bui lding and also has important role in saving energy in conditioning building, and roof considered the major part of the building 
envelope, attention was focused on the roof. In Egypt the thermal effect of roof is increased as one go towards from north to s outh.

In Egypt different field measurements and theoretical studies were carried out to investigate the thermal performance of the traditional houses under the effect of local external climatic conditions of Cairo region $\left(30^{\circ} \mathrm{N}\right)^{(2,3)}$. The results of these studies showed that dry and spray water shading roofs devices, insulating roof, air gap roof, double walls and ventilated double walls improve the internal environmental conditions. Theoretical and experimental study was carried out to investigate the the rmal performance of a pre-fabricated concrete flat in 15 May city, and clear that reasonable agreement between the theoretical and experimental indoor air temperature of the flat is achieved ${ }^{(4)}$. Saving energy consumption in hot arid region and the effect of nocturnal radiation in increasing the thermal efficiency of the building was studied theoretically under the climatic conditions of Aswan $\left(24^{\circ} \mathrm{N}\right)$, Egypt. This study showed that, thermal insulation thickness of about $5-7 \mathrm{~cm}$ thick in roof help in reducing the total thermal transmittance (U-Value) to be $0.4 \mathrm{~W} / \mathrm{m}^{20} \mathrm{C}$, which is the favorable value in Upper Egypt. This thickness led to save cooling load by about $80 \%$ in conditioned building. Ventilating the shaded roof increase the effect of the shading and movable s hading help the usefulness of nocturnal radiation in night hours ( ). The requirement for building in the Waste Costal of Red See (Ghardaga) was carried out ${ }^{(6)}$. Evaluating the external climatic conditions of Toshky region $\left(23.5^{\circ} \mathrm{N}\right)$, Egypt and evaluating the thermal performance of some traditional building built their, give us a picture view about the climate of Toshky and the periods of warm, hot and very hot in it. This study shows that using Nobaa sandstone in wall alone is not favorable. The study also shows that domes or vault built from concrete without using material with special thermal characteristics is not the solution, and if dome hasn't top opening to loss the hot air, a hot heat island is found and led to discomfort ${ }^{(7,8 \& 9)}$. A developed new building material with three line defense of thermal insulation used in walls and apply the concept of domes and vault with good thermal insulation help in valid the thermal comfort in building in Toshky region, and let the indoor environmental condition of the building to be within the comfort zone in the very hot and dry period in summer ${ }^{(10)}$. The thermal performance of exposed composed roofs in very hot dry desert region in (Toshky) region, Egypt was carried out and investigate that; the construction roo f systems (insulated concrete, double, planted and un-insulated concrete roofs) valid an indoor air temperature thermal damping of about $96 \%, 90 \%, 89 \%$, and $76 \%$ respectively, the green roof gives the lower indoor air temperature, due to the evaporation process, and the indoor air temperature of room with active concrete roof can improved by shading this roof and using good thermal conductivity tube material like stanlistail ${ }^{(11)}$. The thermal performance of building envelope in very hot dry desert region in Egypt (Toshky Region) was carried out and investigate that; Nobaa sand stone in walls alone falls to valid thermal comfort due to the high storage, high thermal mass and thermal conductivity of it. The indoor air temperature of hollow clay brick and light sand block have approximately the same thermal performance through the day time and they nearest to the upper limit of thermal comfort ${ }^{(12)}$. Theoretical and experimental studies were carried out to evaluate the thermal performance of building with differe nt building envelope in different country. The thermal performance of building and optimization the thermal insulation thickness in walls were studied ${ }^{(13)}$. The thermal performance of a vegetated cladding system on facade walls was also study ${ }^{(14)}$. Experimental approach to the contribution of plant covered building envelops were study ${ }^{(15)}$. The effect of thermal mass walls to reduce building heating or cooling load regards as one of the most effective way where using massive building envelop components delay and flatten thermal waves caused by external temperature swings ${ }^{(16)}$. In Mediterranean countries theoretical and experimental study was carried out to evaluate the thermal performance of building. The ventilating roofs have been widely used, the effect of roof tiles on the thermal performance of ventilated ducts were studied, and 
indicate that the presence of air permeable layer and elements to protect the ventilation duct eliminate any difference in performance which were due to the cross section of the ventilation duct ${ }^{(17 \& 18)}$. The finite element model was carried out to investigate the thermal performance of non air conditioned buildings with vaulted roof and flat roof. It clear that building with a vault roof have lower indoor air temperature comp ared to those with a flat roof, that is because such roof dissipate more heat by convection and thermal radiation at night due to the enlarged curved surfaces ${ }^{(19)}$. Different insulation materials (mineral wool, polyurethane, and polystyrene) were used to evaluate the thermal performance of building for decreasing the thermal demand and heating and cooling load ${ }^{(20)}$. The usefulness of low earth temperature was discussed theoretically and experimentally to show the effect of earth-pipe -air heat exchanger systems in reducing the cooling load of building in summer (21). Previously theoretical and experimental study was carried out using different passive approach; shading, insulation, roof pond, movable shading, and evaporative cooling for roof ${ }^{(22-28)}$. All these study show that applying different passive approaches help in improving the indoor air temperature of building. This study deals with the evaluation of bio-climatic analysis East ElOwauinat region. Also investigate the effect of external climatic con dition and thermophysical characteristics and thermo-physical properties of building materials on and thermal performance of residential building to valid comfort and save energy in Owauinat region according to Egyptian residential code ${ }^{(29)}$.

\section{CLIMATIC FACTOR}

The outdoor climatic condition (outdoor air temperature, relative humidity, solar intensity, and wind speed) are the main factors affecting on the thermal performance of the building in any region.

\subsection{The Outdoor Air Temperature and Relative Humidity}

Figure (1.a) shows the monthly mean maximum and monthly mean minimum of the outdoor air temperature of East El-Owauinat. The figure shows that the monthly mean maximum / minimum temperature increase gradually from January till reaches it's ma ximum value of about $35-40^{\circ} \mathrm{C}$ through May, June, July, August and September and then began to decrease. Figure (1.b) shows the monthly mean maximum / minimum relative humidity in East El Owauinat seems to be decreased gradually fr om January to reach minimum value of $12 \%$ in May June and July then began to increase slowly starting from August . It is clear that through summer season in East El-Owauinat the low value of relative humidity with the high value of dry temperature help in using the concept of evaporative cooling in East El -Owauinat in general and a in special case in building to valid the thermal comfort for people.

\subsection{The Solar Intensity Incident on Horizontal and Different Orientations}

Figure (2) shows the calculated solar radiation fallen on the horizontal surface and different orientations on East El-Owauinat region, during summer (JULY, 21) seasons. From Figure (2.a) we can conclude that the south orientation is the best orientations received minimum values of solar intensity during summer season, and this help in making control on the solar radiation fallen on the south orientation. The figure also demonstrate that the horizontal surface receives the greatest amount of solar intensity and its maximum va lue reach to be $1025 \mathrm{~W} / \mathrm{m}^{2}$ at noon and still over $800 \mathrm{~W} / \mathrm{m}^{2}$ for about 7 hours. The east and west direction receive high amount of radiation reach to about $733 \mathrm{~W} / \mathrm{m}^{2}$ at 8:00 $\mathrm{AM}$ for the east and at 16:00 PM for the west directions. Also the figure clear the amount of solar intensity fallen on the north direction in the morning and afternoon. Figure (2.b) shows the sun path diagram and the variation of shadow forming on the different direction at noon. 


\section{DIFFERENT METHODS OF EVALUATING THE THERMAL PERFORMANCE OF BUILDINGS}

There are many methods to evaluate the thermal performance of buildings. The first approach related to comfort standards. This method is called Bio-climatic method, which has been proposed for buildings that take more passive approac $\mathrm{h}$ for heating and cooling in areas where acceptable humidity can be maintained. The second method is the experimental methods. In this method temperature distribution through the building envelope surfaces and thermal performance is determined experimentally and evaluated. The third approach is the mathematical and simulation method, which is carried out by energy software programs.

\subsection{Bio-Climatic Method}

There are many different Bio-climatic methods used for evaluate the thermal performance of building envelope. These methods are dependent on the external climatic conditions of the location and the approach of thermal comfort. The famous three Bio -climatic methods are Olgay comfort chart, Mahony tables and the psychometric charts developed by Givoni and psychometric charts developed by ASHREA ${ }^{(30-34)}$. In Egypt many studied were carried using these tools ${ }^{(35 \& 36)}$ some of them divided Egypt to six climatic zones ${ }^{(37-39)}$. Bioclimatic charts facilitate the analysis of the climate characteristics of a given lo cation from the viewpoint of human comfort, as they present, on a psychrometric chart, the concurrent combination of temperature and humidity at any given time.They can also specify building design guidelines to maximize indoor comfort conditions when the building's interior is not mechanically conditioned. All such charts are structured and refer to, the comfort zone.

\subsection{Experimental Technique}

There are two types of experimental techniques, which are used to determine the thermal performance and energy efficiency of building under the different external climatic conditions of different seasons.

\subsubsection{The First Technique}

Temperatures distribution through the envelope elements, indoor air, mean radiant temperatures, and internal surfaces tempera tures are measured and recorded for at least three days under the effect of external climatic conditions of different seasons. Internal and external relative humidity, solar radiation, and wind speed also measured and recorded. Damping factor, decrement factors, and time lag of the building envelope were determined ${ }^{(2,3 \& 10)}$. Also the human degree of sensitivity to the indoor climate is measured and determined by using the indoor weather stations. In which the human degree of sensitivity is given by the Pr edicted Mean Vote (PMV) value which lies between -3 and 3 is a set of environmental variables, which satisfies Fanger comfort equation produces optimum comfort, table $(1)^{(32)}$. The instrument which measures simultaneously the PMV and PPD values were developed by Korsgaard and Madsen ${ }^{(40)}$.

Table (1): Predicted Mean Vote (PMV) according Fanger Equation

\begin{tabular}{|l|c|c|c|l|l|l|l|}
\hline Case & $\begin{array}{l}\text { Very } \\
\text { cold }\end{array}$ & $\begin{array}{l}\text { Coole } \\
\text { d }\end{array}$ & Cool & $\begin{array}{l}\text { Comfo } \\
\text { rt }\end{array}$ & Warm & Hot & $\begin{array}{l}\text { Very } \\
\text { hot }\end{array}$ \\
\hline PMV & -3 & -2 & -1 & & & & \\
\hline
\end{tabular}




\subsubsection{The Second Technique}

The second technique is that used for evaluating energy consumption in the building. It is a technique for measuring the energy consumed, for cooling/heating loads, lighting, equipment's...etc by using voltmeter analysis stations. These measurements are contributing in the field of electrical planning of any countries, and also to know how energy efficiency can be improved. This method of measurement is adequate in the case of commercial building rather than in the case of residential buildings ${ }^{(41)}$.

\subsection{THE MATHEMATICAL MODEL FOR THERMAL EVAL UATION OF BUILDING AND SIMULATION METHOD TECHNIQUE}

\subsubsection{Analytical Study}

The thermal response of building is defined as the reaction of the building envelope to some form of heat input and the amount of internal loads. It depends mainly on ori entation, size, windows to wall ratio, also on the thermo physical and optical properties of the building materials, and on the external environmental conditions. Heat transfer in building takes place by three simultaneous modes; conduction, convection and radiation. Heat is also transfer by ventilation and stored in the building fabric. The general equation governing the heat flow through a homogeneous layer in one dimension is written as ${ }_{(42)}$;

$$
\mathrm{k}\left(\partial^{2} \mathrm{~T} / \partial \mathrm{x}^{2}\right) \quad=\rho \mathrm{C}_{\mathrm{p}}(\partial \mathrm{T} / \partial \mathrm{t})
$$

Where; $\mathrm{T}$ is the temperature $\left({ }^{\circ} \mathrm{C}\right), \mathrm{x}$ is the space dimension $(\mathrm{m}), \mathrm{t}$ is the time $(\mathrm{sec}), \mathrm{k}$ is the thermal conductivity $\left(\mathrm{W} / \mathrm{m}^{\circ} \mathrm{C}\right), \rho$ is the density $\left(\mathrm{kg} / \mathrm{m}^{3}\right), \mathrm{C}_{\mathrm{p}}$ is the specific heat; $\left(\mathrm{J} / \mathrm{kg}{ }^{\circ} \mathrm{C}\right)$

The boundary conditions assumed to solve this equation at the outside and inside surfaces are given as:

$$
\begin{aligned}
& \mathrm{k}(\partial \mathrm{T} / \partial \mathrm{x})_{\mathrm{x}=0}=\mathrm{h}_{\mathrm{so}}\left(\mathrm{T}_{\mathrm{so}}-\mathrm{T}_{\mathrm{si}}\right) \\
& \mathrm{k}(\partial \mathrm{T} / \partial \mathrm{x})_{\mathrm{x}=1}=\mathrm{h}_{\mathrm{si}}\left(\mathrm{T}_{\mathrm{si}}-\mathrm{T}_{\mathrm{ai}}\right)
\end{aligned}
$$

Where; $\mathrm{T}_{\mathrm{so}}$ and $\mathrm{T}_{\mathrm{si}}$ are the outside / inside surface temperature $\left({ }^{\circ} \mathrm{C}\right), \mathrm{T}_{\mathrm{ao}}$ and $\mathrm{T}_{\mathrm{ai}}$ are the outdoor / indoor air temperature $\left({ }^{\circ} \mathrm{C}\right), \mathrm{h}_{\mathrm{so}}$ and $\mathrm{h}_{\mathrm{si}}$ are the heat transfer coefficient of the outside/inside surface including the radiation and convection components $\left(\mathrm{W} / \mathrm{m}{ }^{2}{ }^{\circ} \mathrm{C}\right)$,

There are many complex mathematical methods to solve the equations of heat transfer through the building envelope, from which the matrix method. ${ }^{(42)}$ The admittance procedure using the matrix solution to estimating the energy transfers and temperature changes under steady cyclic conditions. It determines the temperature dependent on the daily mean and swing about the mean by the calculation of the thermal characteristics ( $\mathrm{Y}$-value; Y, decrement factor; $\lambda$, time lag; $\varphi$, surface factor; Sf of multi-layer construction ${ }^{(43 \& 44)}$.

\subsubsection{Thermal Transmittance}

Other simple method used to determine the thermal efficiency of the building envelop e is the total thermal transmittance (U-Values) of roofs and walls. The total U-Value of the building can be determined as follows ${ }^{(45-47)}$,

$$
\begin{aligned}
\mathrm{Uo}= & \{\mathrm{U} 1 \mathrm{~A} 1+\mathrm{U} 2 \mathrm{~A} 2+\mathrm{UiAi} \ldots \ldots \ldots . \mathrm{UnAn}\} / \mathrm{Ao} \\
& \mathrm{Ui}=\{\mathrm{UsAs}+\mathrm{UgAg}\} / \mathrm{Ai}
\end{aligned}
$$

Where:

$\mathrm{Ai} \quad=$ Area of wall no $\mathrm{i}, \mathrm{m}^{2}$

As $\quad=$ Area of solid part, $\mathrm{m}^{2}$ 
$\mathrm{Ag} \quad=$ Window area, $\mathrm{m}^{2}$

Uo = Total thermal transmittance, $\left(\mathrm{W} / \mathrm{m}^{2}{ }^{\circ} \mathrm{C}\right)$

$\mathrm{Ui}=$ Thermal transmittance of wall $\mathrm{i},\left(\mathrm{W} / \mathrm{m}^{2}{ }^{\circ} \mathrm{C}\right)$

$\mathrm{Ug}=$ Thermal transmittance of windows including glass and frame, $\left(\mathrm{W} / \mathrm{m}^{2}{ }^{\circ} \mathrm{C}\right)$

The U-Value for any composite construction element can be written as follows

Where:

$$
\mathrm{U}=\{1 / \mathrm{hao}+\Sigma(\mathrm{Li} / \mathrm{ki})+1 / \mathrm{hai}\}
$$

$\mathrm{Li}=$ Thickness of layer no $\mathrm{i},(\mathrm{m})$

ks $\quad=$ Thermal conductivity of layer $\mathrm{i},\left(\mathrm{W} / \mathrm{m}^{\circ} \mathrm{C}\right)$

hai,hao $=$ Heat transfer Coefficient of internal and exte rnal surfaces, $\left(\mathrm{W} / \mathrm{m}^{2}{ }^{\circ} \mathrm{C}\right)$

\subsubsection{The Over all Heat Transfer Coefficient}

The over all heat transfer coefficient of walls and roofs is other method used. Different international codes calculate the over all heat transfer value of walls and roofs according to the heat gain in summer season for the solid part and windows by conduction and from the solar gain by radiation from windows as follows ${ }^{(48-50)}$,

OTTVi = U Ai (1-WWR) $\Delta$ TDeq+ Ug Ag WWR $\Delta \mathrm{T}+$ Ag WWR(1-SGR)SFSC

Where:

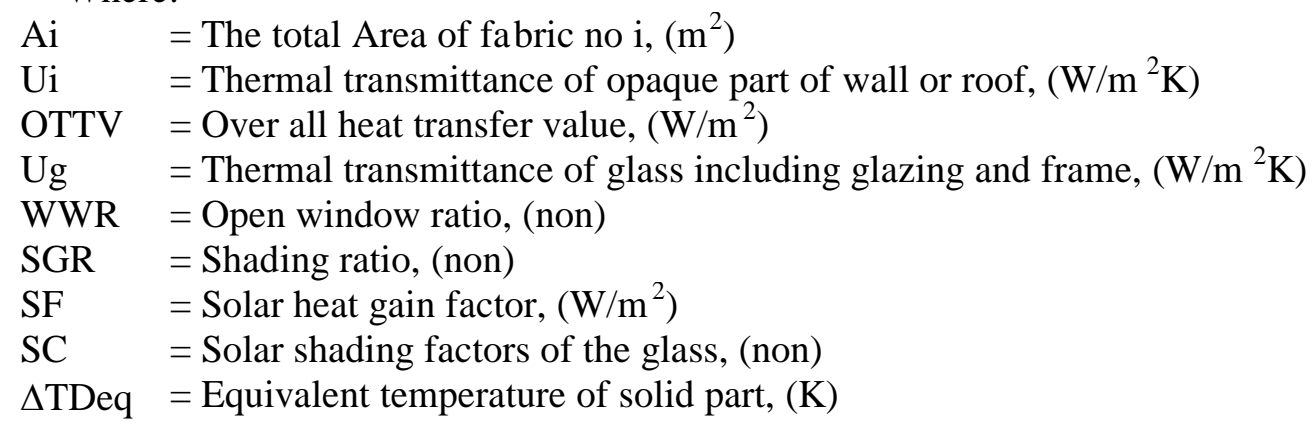

Table (2) shows the calculated Over all Heat Transfer (OTTV) in Different Climatic Zones ${ }^{(29)}$

Table (2): The Over all Heat Transfer (OTTV) in Different Climatic Zones

\begin{tabular}{|l|l|l|c|c|}
\hline Zones & Alex. & Cairo & ASUIAT & ASWAN \\
\hline Roofs & $20-25$ & $20-25$ & $20-25$ & $20-25$ \\
\hline Walls & 40 & 45 & 50 & 55 \\
\hline
\end{tabular}

\subsubsection{Simulation Method}

There are hundreds of energy analysis tools and methods that are u sed worldwide to predict the potential savings of energy conservation measures. In the Italy energy institute developed simulation program called PSS $6^{(51)}$, while in the USA, DoE2 provides an up to date listing of selected building energy software (DoE-2000) ${ }^{(52)}$. Generally, the existing energy analysis tools can be classified into either forward or inverse methods. The energy predictions are based on physical properties of the building systems such as geometry, location, construction details, and HVAC system type and operation. Most of the existing detailed energy simulation tools such as DoE-2, TRANSYS, Calpas $3^{(53)}$ and F-Load ${ }^{(54)}$ follow the forward modeling 
approach. It is clear from the analysis of different energy software which was carried out by the authors and the measurements there still a big difference between the simulation methods and experimental methods, these differences may be due to the simplest assumptions in mathematical models. New software programs are the Design Builder and ECTDEC ${ }^{(55,56)}$.

\section{CASE STUDY}

To illustrate the thermal performance of building in East El-Owauinat, a one design of EBNY BAIATIC project developed by the Egyptian government was chosen. Figure (3) shows a plan of flat in the upper storey of this building. The building analyzed in this study is of $63 \mathrm{~m}^{2}$ floor area. The building has the following description. Walls consist of $25 \mathrm{~cm}$ clay brick with density $1790 \mathrm{Kg} / \mathrm{m}^{3}$, and inside and outside plaster layer. Roof consists of reinforced concrete with thickness $15 \mathrm{~cm}$ covered with/without thermal insulation layer with thickness $8 \mathrm{~cm}$ from expanded polystyrene and finished by cement tiles and sand. Figure ( $4 \& 5$ ) show a cross section in the wall and roof with the thermo-physical properties and characteristic of the $\mathrm{m}$. Window is considered as traditional window. The opening used glass of $6 \mathrm{~mm}$ ( $\mathrm{SC}=0.8$ ), and its U-Value is $5.4 \mathrm{~W} / \mathrm{m}^{20} \mathrm{C}$. ECOTECT V5 software computer program was used for this investigation. The reception room was chosen as a unit for the study. The thermal performance of the building was carried out in different direction, carried out on the building using ventilation in night and all day and finally by using / not using thermal insulation in roof and walls alternative walls and roofs to reach to the favorite $\mathrm{R}$-value required in this region according the Egyptian code.

\section{RESULTS AND DISCUSSION}

\subsection{Bio-Climatic Analysis of Owauinat}

The thermal comfort of human being is governed by many physiological mechanisms of the body and these vary from person to person. In any parti cular thermal environment it is difficult to get more than $50 \%$ of the people affected to agree that the conditions are comfortable. Personal (activity, clothing, age and sex) and physical environmental variables (air temperature, mean radiant temperature, relative humidity and wind speed) are the principle factors affecting the human thermal comfort. Olgay ${ }^{(30)}$, Mahony tables ${ }^{(31)}$, Givoni chart $^{(57)}$,....etc is simplest methods and depends on the external climatic condition, they did not give a complete configuration about the thermal performance of the building and its thermal load which valid the thermal comfort for the occupants. The bio-climatic analysis of Owauinat with Mahony tables investigates that, the planning of city must be compact and the opening must be less than $20 \%$. The walls and roof must be heavy with thermal insulation in the outer layer to decrease the heat capacity of the building and also to be as line defiance in the extreme time ${ }^{\text {(Authors) }}$.

On other side a formula determined the "indoor Comfort" temperature, $\mathrm{T}_{\mathrm{n}}$ relative to an exponentially weighted running average outdoor temperature, $\mathrm{T}_{\mathrm{o}}$ and applicable to free running building without mechanically narrowly controlled indoor temperature was developed as follows ${ }^{(58)}$.

$$
\mathrm{T}_{\mathrm{n}}=17.6+0.31 * \mathrm{~T}_{\mathrm{o}}
$$

within the limitation that $17.8{ }^{\circ} \mathrm{C}<\mathrm{T}_{\mathrm{n}}<29.5^{\circ} \mathrm{C}$.

Where,

$\mathrm{T}_{\mathrm{n}} \quad=$ neutrality temperature

$\mathrm{T}_{\mathrm{o}} \quad=$ Monthly mean outdoor temperature

Table (3) shows the upper/lower limit temperature $\left(T_{n} \pm 2\right)$ of the comfort zone in Owauinat. 
By determining the upper and lower limit of comfort we can reach to the ratio of heating, shading and cooling requirement in Owauinat by using the estimated hours temperatur e by Novel ${ }^{(59)}$. Table (4) shows the estimated hours temperature for Owa uinat While people in this region may be compatible with a high temperature. From the table we can investigate that, the ratio need for shading in Owauinat reach to be about $73 \%$, the need for using mechanical cooling unit reach to about $24 \%$, while the need for warming reach to about $27 \%$, and there is about $49 \%$ of hours per year is comfortable. From this table we show that shading and controlling the amount of solar intensity reach to building lies in the first in making the building suitable with its external environment.

Givoni's and ASHREA psychometric charts, aimed to predicting the indoor conditions of the building according to the outdoor prevailing conditions and based on the linear relationship between the temperature amplitude and vapour pressure of the outdoor air in various regions. The chart combines different temperature amplitude and vapour pressure of the ambient air plotted on the psychrometric chart and correlated with specific boundaries of the passive cooling techniques overlaid on the chart. These techniques include evaporative cooling, thermal mass, naturalventilation cooling and passive heating. These techniques can be used at the pre-design analysis stage for asses sing the climate, establishing the thermal control task (The thermal control task can be defined as the difference between the given climatic conditions and the desirable indoor conditions ) and selecting the appropriate passive control techniques. Figure (6) shows the design strategies on ASHRE psychometric chart with the designed comfort of Owauinat and the extended zone for using ventilation, thermal mass, evaporative cooling, passive heating and mechanical heating and air conditioning. The Figure shows that in winter season the climate of Owa uinat region is near to the comfort zone and using the passive heating system tasks make the building to be in the comfort region. In summer season the figure shows that this region need extensive way to the cooling requirement, and using shading, green area and evaporative cooling help the climate of the building to enter the comfort zone.

Table (3): the upper / lower limit temperature of the comfort zone during the summer season in Owauinat region .

\begin{tabular}{|l|c|c|c|c|c|c|c|c|c|c|c|c|}
\hline Months & Jan & Feb & Mar & Apr & May & Jun & Jul & Aug & Sep & Oct & Nov & Dec \\
\hline $\begin{array}{l}\text { Max. } \\
\text { Temperature }\end{array}$ & 18.9 & 20.9 & 24.2 & 32 & 35.6 & 38.2 & 38.2 & 36.9 & 35.4 & 33.6 & 25.3 & 21.1 \\
\hline $\begin{array}{l}\text { Min. } \\
\text { Temperature }\end{array}$ & 4.4 & 5.6 & 9 & 15.4 & 19.8 & 22.1 & 25.1 & 22.4 & 20.8 & 14.7 & 10.6 & 7 \\
\hline $\begin{array}{l}\text { Avg. } \\
\text { Temperature( } \\
\text { Tom }\end{array}$ & 11.7 & 13.3 & 16.6 & 23.7 & 27.7 & 30.2 & 31.7 & 29.7 & 28.1 & 24.2 & 18 & 14.1 \\
\hline $\begin{array}{l}\text { Upper limit } \\
\text { of comfort }\end{array}$ & 23.2 & 23.7 & 24.7 & 26.9 & 28.2 & 28.9 & 29.4 & 28.8 & 28.3 & 27.1 & 25.2 & 24 \\
\hline $\begin{array}{l}\text { Lower limit } \\
\text { of comfort }\end{array}$ & 19.2 & 19.7 & 20.7 & 22.9 & 24.2 & 24.9 & 25.4 & 24.8 & 24.3 & 23.1 & 21.2 & 20 \\
\hline
\end{tabular}

Figure (7) shows the hourly distribution of the outdo or air temperatures and the hourly estimated environmental indoor temperatures inside the reception room in East El -Owauinat on July 21 at different orientations. The figure shows that the outdoor air temperature continue over $30^{\circ} \mathrm{C}$ for more than 10 hours and this led to case high thermal stress on people in this region. The reception room was investigated in different directions. We can notes that in all directions the environmental indoor temperatures still high in day and night, that are 
because there is no ventilation used and the exposed of the roof to high insulation flux over $800 \mathrm{~W} / \mathrm{m}^{2}$ for about 7 hours and the high outdoor air temperature. Also we can notes from the figure that the environmental indoor temperatures of the north direction give the lower on with respect to the other.

Figure (8) shows the hourly distribution of the outdoor air temperatures and the hourly estimated environmental indoor temperatures inside the reception room with/ without using thermal insulation in East El-Owauinate on July 21. The best case of north direction was chosen to make a comparison of the environmental indoor temperatures without and with thermal insulation in the roof and walls. The figure illustrate that the presence of thermal insulation help in making the envir onmental indoor temperatures approximately stable all the day and lower than that the case without insulation. The the $\mathrm{U}$-value of the roof change from 1.919 to $0.356 \mathrm{~W} / \mathrm{m}^{20} \mathrm{C}$ and the walls from to 1.5 to $0.726 \mathrm{~W} / \mathrm{m}^{20} \mathrm{C}$ by adding thermal insulation, which valid the Egyptian Code R-value requirements in this area.

Table (4): The Two Hours Estimated Temperature for East El-Owaiunat.

\begin{tabular}{|c|c|c|c|c|c|c|c|c|c|c|c|c|c|}
\hline Monthes & & Jan & Feb & Mar & Apr & May & Jun & Jul & Aug & Sep & Oct & Nov & Dec \\
\hline Tmax. & & 18.9 & 20.9 & 24.2 & 32 & 35.6 & 38.2 & 38.2 & 36.9 & 35.4 & 33.6 & 25.3 & 21.1 \\
\hline Tmin. & & 4.4 & 5.6 & 9 & 15.4 & 19.8 & 22.1 & 25.1 & 22.4 & 20.8 & 14.7 & 10.6 & 7 \\
\hline Trang & & 14.5 & 15.3 & 15.2 & 16.6 & 15.8 & 16.1 & 13.1 & 14.5 & 14.6 & 18.9 & 14.7 & 14.1 \\
\hline Time & $\mathbf{S}$ & \multicolumn{12}{|c|}{ Tow Hour Estimated Temperature } \\
\hline 0 & 0.222 & 8 & 9 & 12 & 19 & 23 & 26 & 28 & 26 & 24 & 19 & 14 & 10 \\
\hline 2 & 0.139 & 6 & 8 & 11 & 18 & 22 & 24 & 27 & 24 & 23 & 17 & 13 & 9 \\
\hline 4 & 0.056 & 5 & 6 & 10 & 16 & 21 & 23 & 26 & 23 & 22 & 16 & 11 & 8 \\
\hline 6 & $\mathbf{0}$ & 4 & 6 & 9 & 15 & 20 & 22 & 25 & 22 & 21 & 15 & 11 & 7 \\
\hline 8 & 0.111 & 6 & 7 & 11 & 17 & 22 & 24 & 27 & 24 & 22 & 17 & 12 & 9 \\
\hline 10 & 0.583 & 13 & 15 & 18 & 25 & 29 & 31 & 33 & 31 & 29 & 26 & 19 & 15 \\
\hline 12 & 0.861 & 17 & 19 & 22 & 30 & 33 & 36 & 36 & 35 & 33 & 31 & 23 & 19 \\
\hline 14 & 1 & 19 & 21 & 24 & 32 & 36 & 38 & 38 & 37 & 35 & 34 & 25 & 21 \\
\hline 16 & 0.917 & 18 & 20 & 23 & 31 & 34 & 37 & 37 & 36 & 34 & 32 & 24 & 20 \\
\hline 18 & $\mathbf{0 . 6 9 4}$ & 14 & 16 & 20 & 27 & 31 & 33 & 34 & 32 & 31 & 28 & 21 & 17 \\
\hline 20 & $\mathbf{0 . 4 4 4}$ & 11 & 10 & 16 & 23 & 27 & 29 & 31 & 29 & 27 & 23 & 17 & 13 \\
\hline 22 & 0.306 & 9 & 10 & 14 & 20 & 25 & 27 & 29 & 27 & 25 & 20 & 15 & 11 \\
\hline
\end{tabular}

\begin{tabular}{|l|l|}
\hline Ratio of warming needed & $27 \%$ \\
\hline Ratio of comfort & $49 \%$ \\
\hline Ratio of cooling needed & $24 \%$ \\
\hline Ratio of shading needed & $73 \%$ \\
\hline
\end{tabular}

Figure (9) shows the hourly distribution of the outdoor air temperatures and the hourly estimated environmental indoor temperatures inside the reception room in East El-Owauinate on July 21 at different ventilation period. The figure shows the effect of using ventilation through 24 hours of the day and using night ventilation period from 20:0PM to 8:0AM. The figure that night ventilation help in reducing the environmental indoor temperatures to be nearest the upper comfort level in night and early hours of the day. We can notes from the figure that if forced ventilation is used by fan the environmental indoor temperatures will be improved and enter the comfort zone. 


\section{CONCLUSIONS}

The building sector in the south of Egypt needs more study and the comfortable strategy must be considered. We can conclude from this study that:

1. Bio-climatic methods are used to verify the first idea of design $f$ or non-conditioning buildings.

2. For non-conditioned building shading devices and control opening areas in the envelope has the first priority.

3. Light color help in decrease the direct share of solar radiation on heat gain through walls.

3. Simulation methods and the parametric analysis are required to evaluate the thermal performance of the building before constructed .

4. Concrete roof slab without thermal insulation case thermal stress in night and early hours of the day on people and this has passive effect on the thermal comfort of people.

5. The required thermal resistance has a minimum $\mathrm{R}$-value $\geq 2.5 \mathrm{~m}^{2} \mathrm{~K} / \mathrm{W}$ for roof and 0.9 $1.3 \mathrm{~m}^{2} \mathrm{~K} / \mathrm{W}$ for walls.

6. thermal insulating materials must be used in all exposed roof to save thermal comfort inside building spaces, where it reduce the effect of thermal radiation during day time hours and also reduce the contribution of mean radiant temperature on the thermal comfort during night during long period of the year, and to conserve energy When mechanical means are used.

7. The environmental indoor air temperature still high inside the building, this due to the high solar intensity fallen in this area and still over $800 \mathrm{~W} / \mathrm{m}^{2}$ for about 7 hours, and high outdoor air temperaturethe which continue over $30^{\circ} \mathrm{C}$ for more than 10 hours. This indoor will modified when all the design strategyneed in this area used.

8. New building materials, smart glass and thermal insulating materials can be used to improve the thermal performance of the building and save energy of buildings in Egypt.

9. Natural night ventilation period from 20:0 PM to 8:AM led to reduce the maximum and minimum environmental indoor air temperature. Also Using fan help in increasing the draw of the moderate outdoor air inside the rooms.

\section{REFERENCES}

1. $\quad$ www. Mht. العوينات|شرق العوينات

2. Khalil, M.H., "Theorelical and Experimental thermal Investigation for A Number of Rooms with the use of insulated Roofs and External shading Devices", M.Sc., Thesis, Cairo University, 84.

3. Abdel Razek, M. M., "Thermal Investigation of Passive Heated and Ventilated Buildings in Egypt", M.Sc., Thesis, Cairo University, 84.

4. M.H. 2007. "Theoretical and Experimental Investigation of the Thermal Performance of A Pre-Fabricated Concrete Flat In 15 May City", HBRC Journal, Vol. 3, No.1 pp. 150-164.

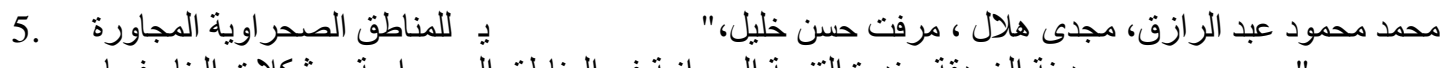

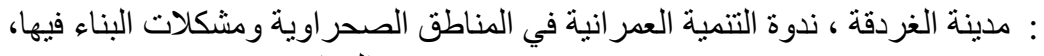
.$$
\text { - الرياض، }
$$

6. Abd El-Razek, M.M, Helal and Khalil, M.H. 2003 “ The Effect of Nocturnal Radiation on the Indoor Climate of Desert Architecture", Al -azhar Engineering $7^{\text {th }}$ International Conference, Cairo, Egypt, 7-10 April, pp. 248-259.

7. First Report 1999. Bioclimatic Studies of Toshky Region and Evaluation of Thermal Performance Rates for some Models Implementing the Region, Housing and Building National Research Center, Cairo, Egypt, June, 1999. 
8. Second Report 2004. Developing an Effective System Building in the Desert Area in Egypt (Toshky Region), Housing and Building National Research Center, Cairo, Egypt.

9. Third Report 2000. Bioclimatic Studies of Toshky Region and Evaluation of Thermal Performance Rates for some Models Implementing the Region, Housing and Building National Research Center, Cairo, Egypt, Febrary.

10. Second Report 2004. Developing an Effective System Building in the Desert Area in Egypt (Toshky Region), Housing and Building National Research Center, Cairo, Egypt.

11. M. H. Khalil, S.S. Sheble, M. S. Morsy, and S. Fakhry, "Thermal Performance of Exposed Composed Roofs in Very Hot Dry Desert Region in Egypt (Toshky)", 2010 International Conference for Enhanced Building Operations (ICEBO 2010)

12. S.S. Sheble, M. H. Khalil, M. A. Helal, and Prof. M. El-Demirdash" " "Thermal Performance of Building Envelope in Very Hot Dry Desert Region in Egypt (Toshky Region)", International Conference for Enhanced Building Operations (ICEBO 2010).

13. Daouas, N., Hassen, Z., Ben Aissia, H. , "Analytical periodic solution for th e study of thermal performance and optimum insulation thickness of building walls in Tunisia", Applied Thermal Engineering, Vol.30, pp. 319-326, 2010.

14. Cheng, C.Y., Cgeung, Ken K.S. Chu, L.M., "Thermal Performance of a vegetated cladding system on façade walls, Building and Environment", Vol.45, pp.1779-1787, 2010.

15. Eumorfopoulou, E.A., Kontoleon, K.J., "Experimental Approach to the Contribution of Plant- Covered walls to the Thermal behaviour of Building Envelops", Building and Environment, Vol.44, pp.1024-1038, 2009.

16. L.Zhu, L., Hurt, R., Correia, D., Boehm, R. , "Detailed Energy Saving Performance analysis on Thermal Mass Walls Demonstrated in a zero energy house", Energy and Building, Vol.41, pp.303-310, 2009.

17. D’Orazio, M., Di Perna, C., Principi, P., Stazi, A., “Effect of Roof Tile on the Thermal Performance of Ventilated Roofs: Analysis of Anunual Performance" Energy and Building, Vol. 40, pp. 911-916, 2008.

18. D’Orazio, M., Di Perna, C., Di Giuseppe, E., "The Effect of Roof Cover ing on the Thermal Performance of Highly Insulated Roofs in Mediterranean Climates, Energy and Building, Avaliable on line 18 April, 2009.

19. Runsheng, T., Meir, I.A., and Wu, T., " Thermal Performance of non air - conditioned buildings with vaulted roofs in comparison with flat roofs", Building and Environment, Vol. 41, No.3, pp. 268-276, 2006.

20. Cabeza, L.F., Castell A., Medrano M., Pérez G., Fernández I. “ Experimental study on the performance of insulation materials in Mediterranean construction ", Energy and Buildings, Volume 42, No.5 5, pp. 630-636, 2010.

21. Bansal V., Misra R., Das Agrawal G., Mathur J. , "Performance analy sis of earth-pipeair heat exchanger for summer cooling", Energy and Buildings, Volume 42, No. 5, pp. 645-648. 2010.

22. Ahmad, A.M., "The Thermal Performance of Concrete Roofs and Reedshading Panel Under Arid Summer Conditions", Overseas Building Notes, BRe, No. 164, October, 1975.

23. Mukhtar, Y.A., "Roofs in Hot Dry Climates, with Special Reference to Northern Sudan ", Overseas Building Notes, BRE, No. 182, October, 1978.

24. Jain, S.P and Rao, K.R., "Movable Roof Insulation in Hot Climates", Buildi ng Research and Practice, Vol.2, No.4, July/August, 1974.

25. Subhash chandra and Subhash chandra, "Temperature Control in a building with evaporatire cooling and variable ventilation ", Solar Energy, Vol.30, No.4, pp.381-387, 1983. 
26. M.S. Sodha, A.K.Khatry and M.A.S. Malik, "Reduction of Heat Flux Through A Roof by Water Film", Solar Energy, vol. 20, pp.189-191, 1978.

27. Nayak, J.K., Srivastava, A., Singh, U. and Sodha, M.S., "the Relative Performance of Different Approaches to the passive Cooling of Roofs" Bul. Env. , Vol. 187, No. 2 , pp.145-161, 1982.

28. Sodha, M.S., Singh, U. and Tiwari, G.N., "A Thermal Model of a pond System with Movable Insulation for Heating A Building ", Building and Environment, Vol.17, No. 2, pp. 135-144, 1982.

29. The Egyptian Residential Buildings Energy Code2006.

30. Victor Olgyay, "Design with Climate", Princeton University, third eddition,k 1969.

31. D.H. Koenigsberger et all, "Manual of tropical housing and design", climatic design, Longmans, 1973.

32. D.A. McIntyre, "Indoor Climate", Applied Science Publishers LTD, London, 1980

33. B.Givoni, "Man climate and Architecture", Second Edition, Applied Science Publishes Ltd, 1976.

34. ASHRAE, "Hand Book of Fundamentals, American, Society of Heating Refrigerating and Air Conditioning Engineers, 1997.

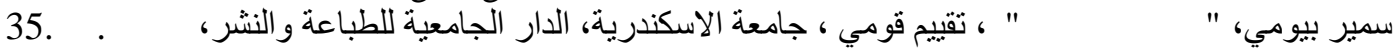

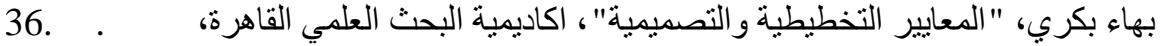

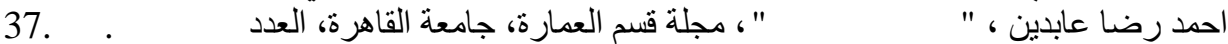

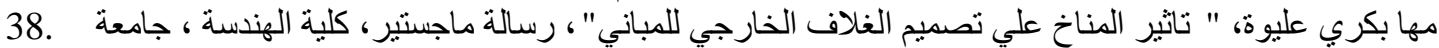

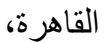

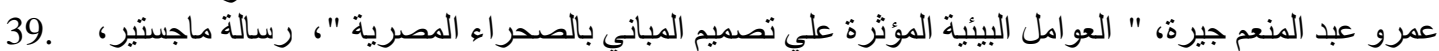
الكلية الفنية العسكرية، القاهرة، العاهة

40. Novell, B. J., "Passive Cooling Strategies" Adesign method, bbased on monthly average temperaturs, has been developed to approximate the need for shading and other stratgies, ASHRAR Journal, Dec. 1983.

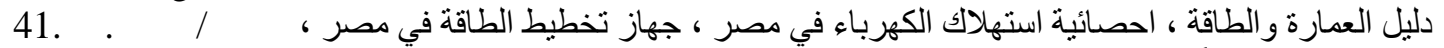

42. Carslow, H. S. and Jaeger, J.C., "conduction of Heat in Solids", $2^{\text {nd }}$ Edition, Oxfored Unversity Press, (1959).

43. Milbank, N.O., and Harrington-Lynn, J., "Thermal Response and the Admittance Procedure", Environmental Temperature Symposium, B.S.E., Vol. 42, May, (1974).

44. Rao, K. R. and Prakash Chandra, "Digital Computer Determination of Thermal Frequency Response of Building Secti ons", Buil. Sci., Vol.1, pp.299-307, 1966.

45. IHVE Guide, Book A, Institute of Heating and Ventilating Engineers, Curiven Press, London. 1970.1970.

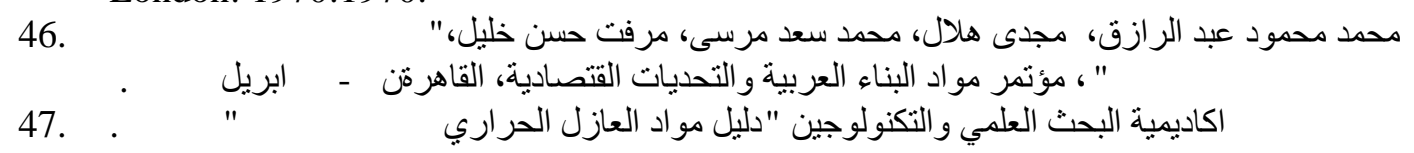

48. Sodha, M.S., bansal, N.K., Kuman,P.K., Malik, A., M.A.S., "solar Passive Building Science and Design", Pergmon Books, 1986.

49. Code of Practice for Overall Thermal Transfer Value in Building, Hong Kong, 1995

50. Khalil, M.H. and Abd El-Razek,M.M. 2004. " The Effect of Building Envelope on Saving Energy Consumption for Building in Hot Arid Region" The $8^{\text {th }}$ Arab International Conference on Materials Science (Materials for Energy Applications), Alexandria, Egypt, pp. 53-63, 18-20 April.

51. Passive Solar system (PSS6), program Handbook S.E.S.S.P.A., Sistemi Energia Suilupro Soft Enirgy System, Italy, 1990.

52. Lawrence Berkeley Univ. of California, USA, Operating Manual of Doe -2, 2000.

53. Berkley Solar Group, Claps 3 Program User Manual, Berkley, Califrinia, 1984. 
54. Beckman, W.A., Duffie, J. A., Klein, S.A., Mitchell, J.W., "F -Load, A Building Heating -Load Calculation Program", ASHREA Transaction, part 2, 1982.

55. www.designbuilder.co.uk

56. www.apps1.eere.energy.gov/buildings/tools_directory/software.cfm

57. Givoni, B.," Climatic consideration in Building and Urban Design", Van Nost rand, 1998.

58. Humphreys, M.A. and Nicol, J.F., "Understanding the Adaptive Approach toThermal Comfort", ASHRAE Transactions 104 (1) pp 991-1004, 1998.

59. Korsgaard, V., and Madsen, T. L. , “ New instruments for measuring thermal comfort”, Proceedings of the 13th International Congress of Refrigeration, Washington D.C., 1971. Vol. 4, pp. 313-322, 1971.

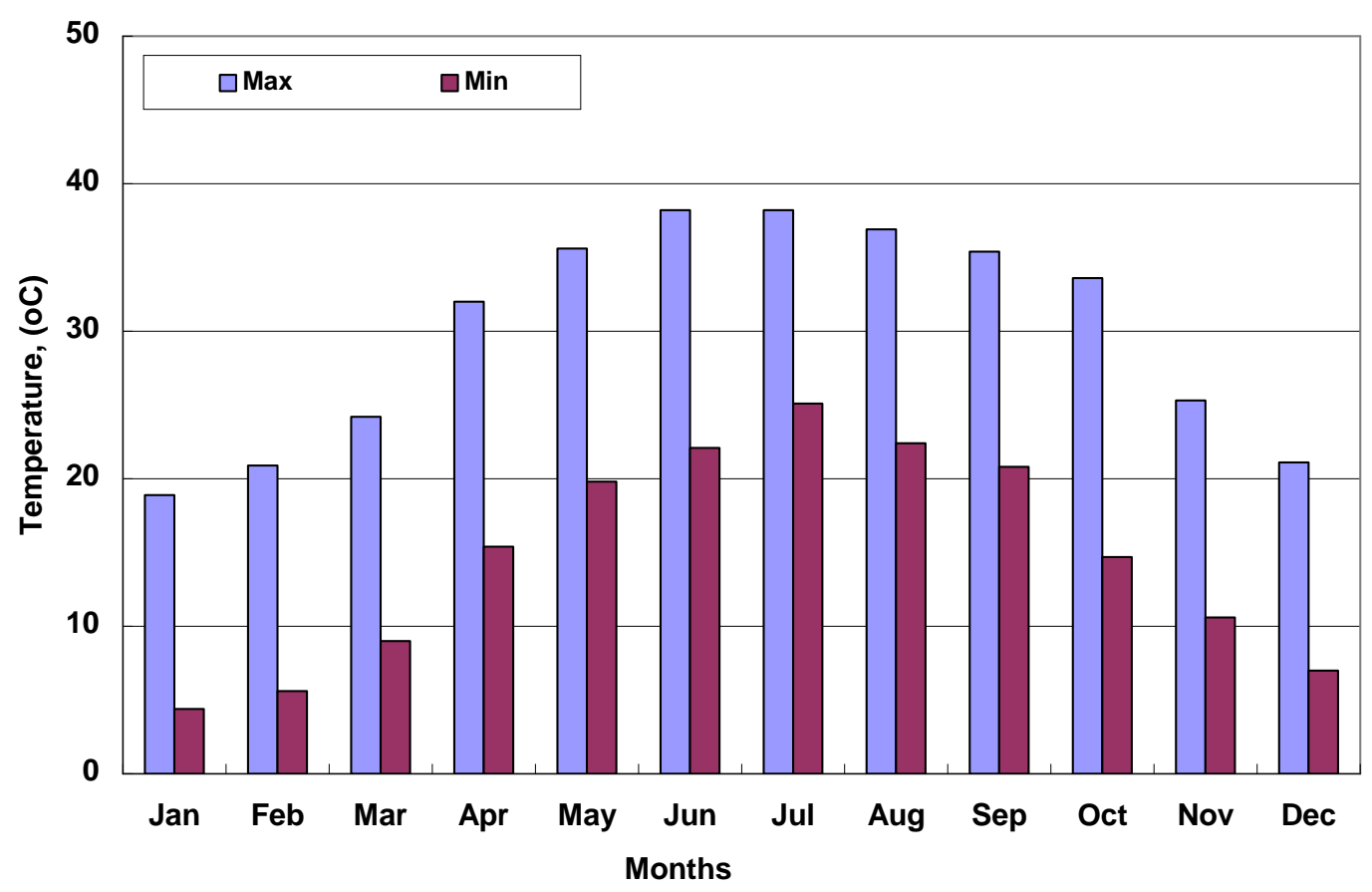

Fig. (1.a) : The monthly mean maximum and monthly mean minimum of the outdoor air temperature of East El-Owauinat. 


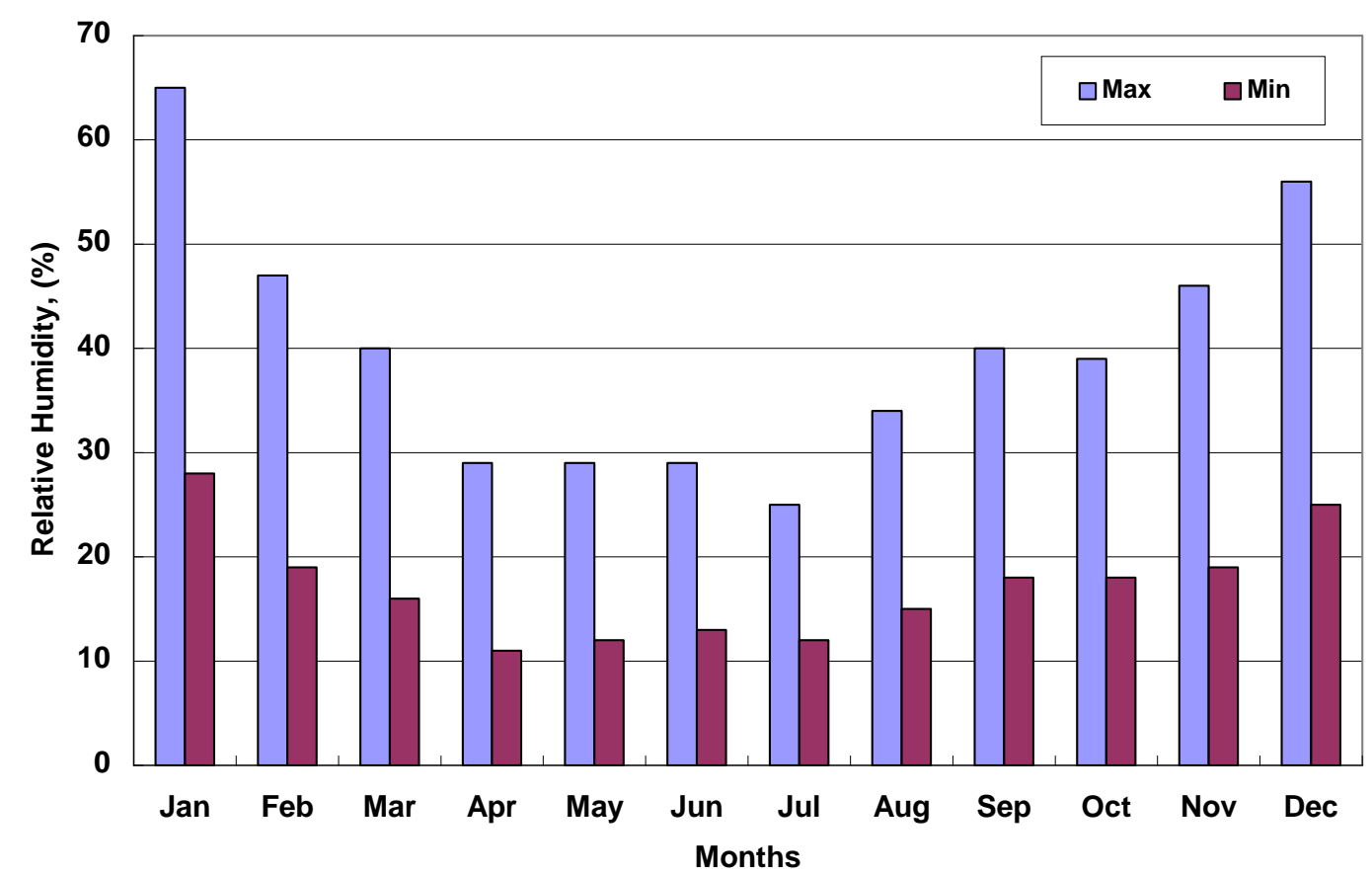

Fig. (1.b) : The monthly mean maximum / minimum relative humidity in East El-Owauinat.

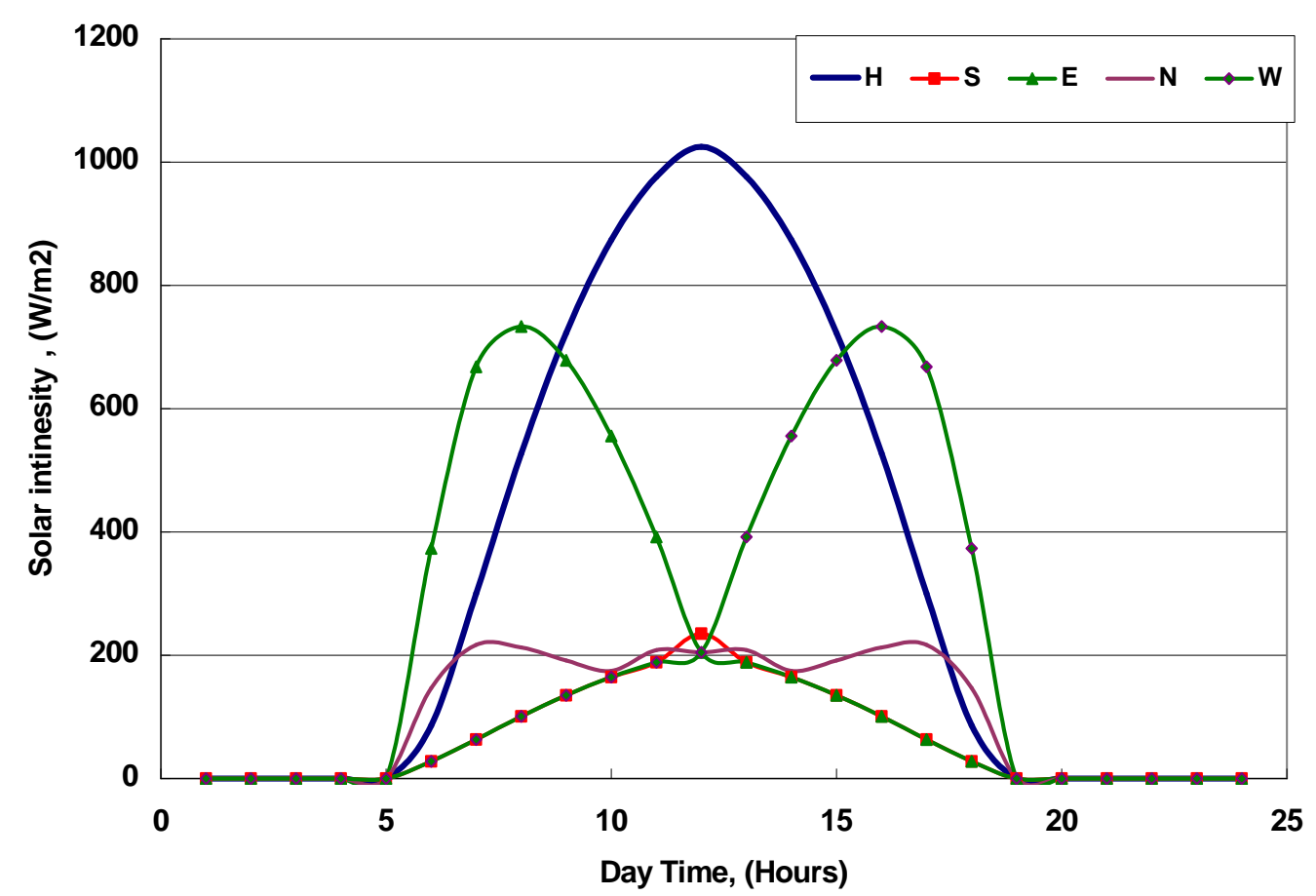

Fig. (2.a) : The calculated solar radiation fallen on the horizontal surface and different orientations on East El-Owauinat region, during summer (JULY, 21) seasons. 


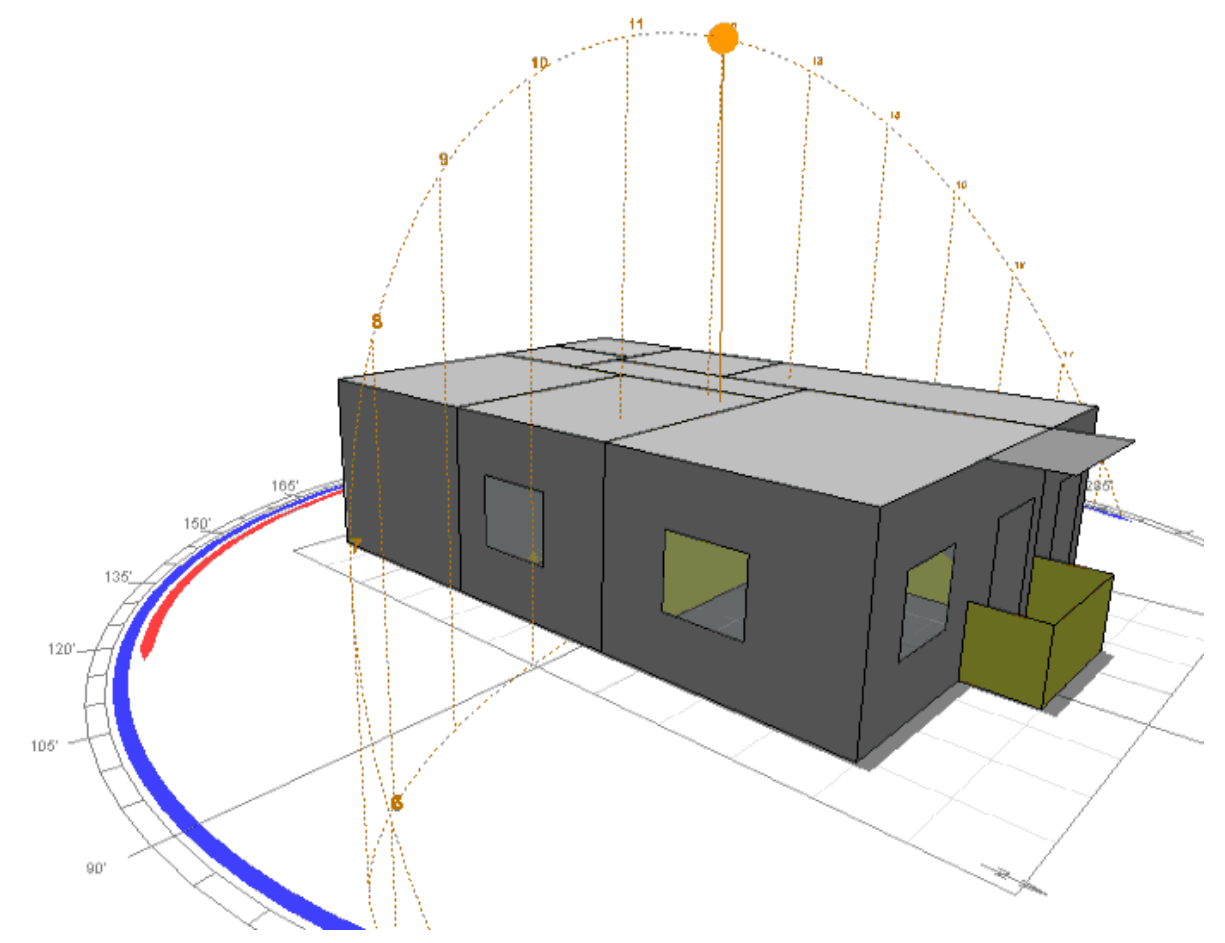

Fig. (2.b) : The sun path diagram and the variation of shadow forming on the different direction at noon.

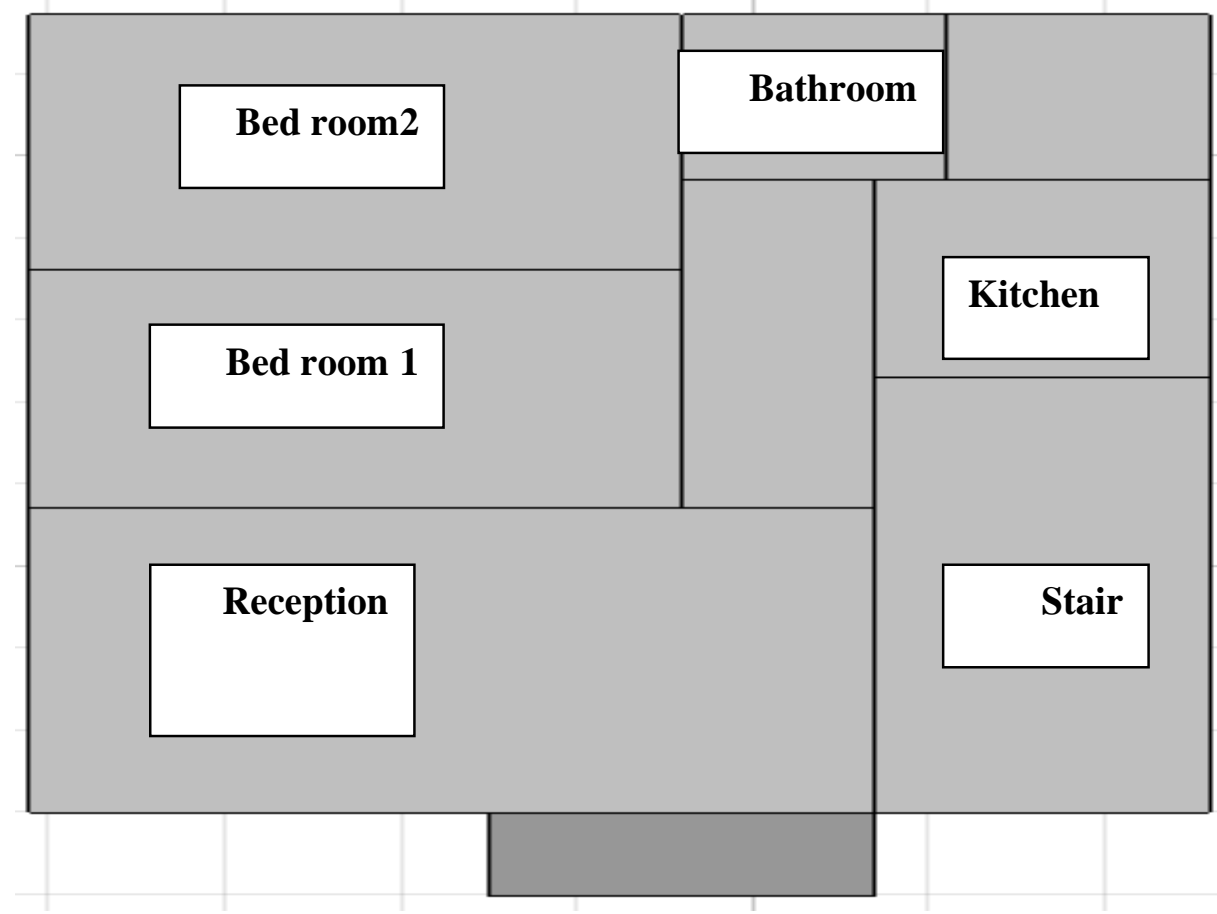

Fig. (3) : A plane of EBNY BAIATIC project developed of East El Owaiunate, Egypt. 


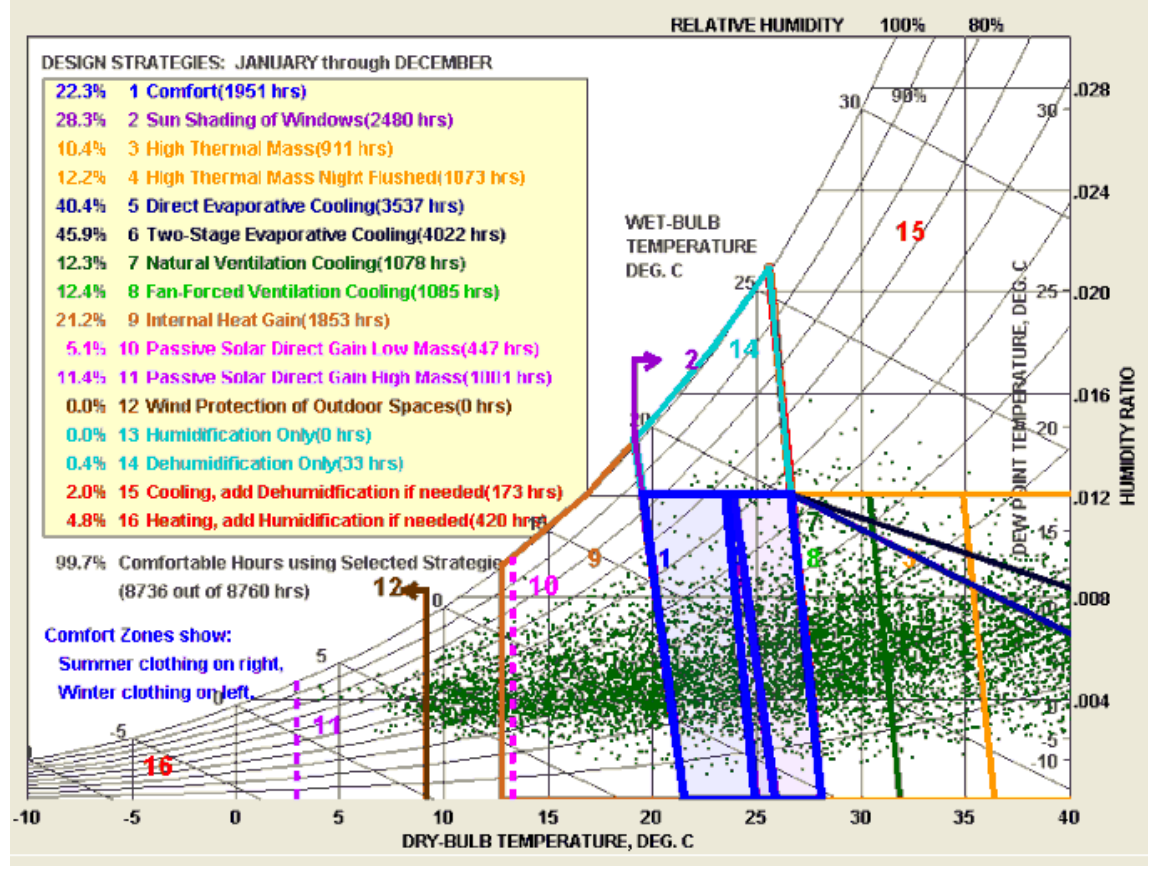

Fig. (6): The bioclimatic analysis of East El Owauinat region with ASHREA.

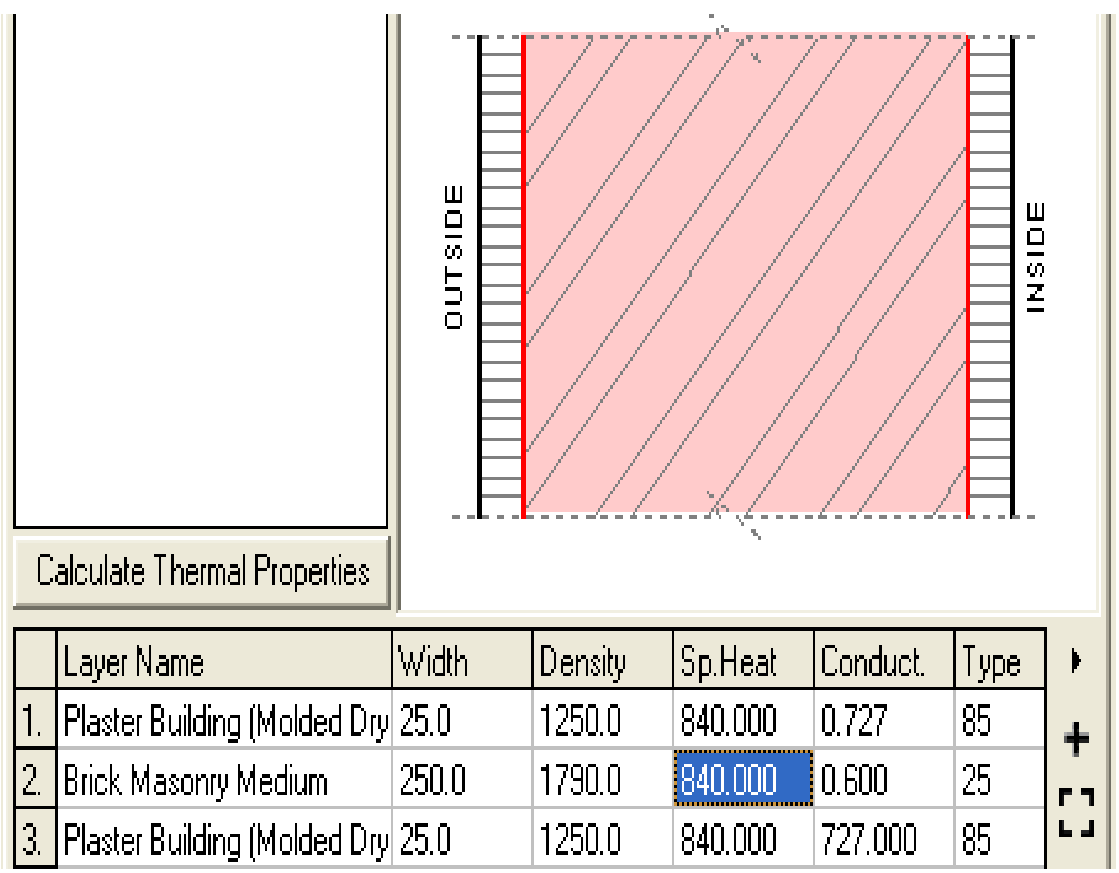


Fig. (4) : A cross section in the wall with the thermo -physical properties.

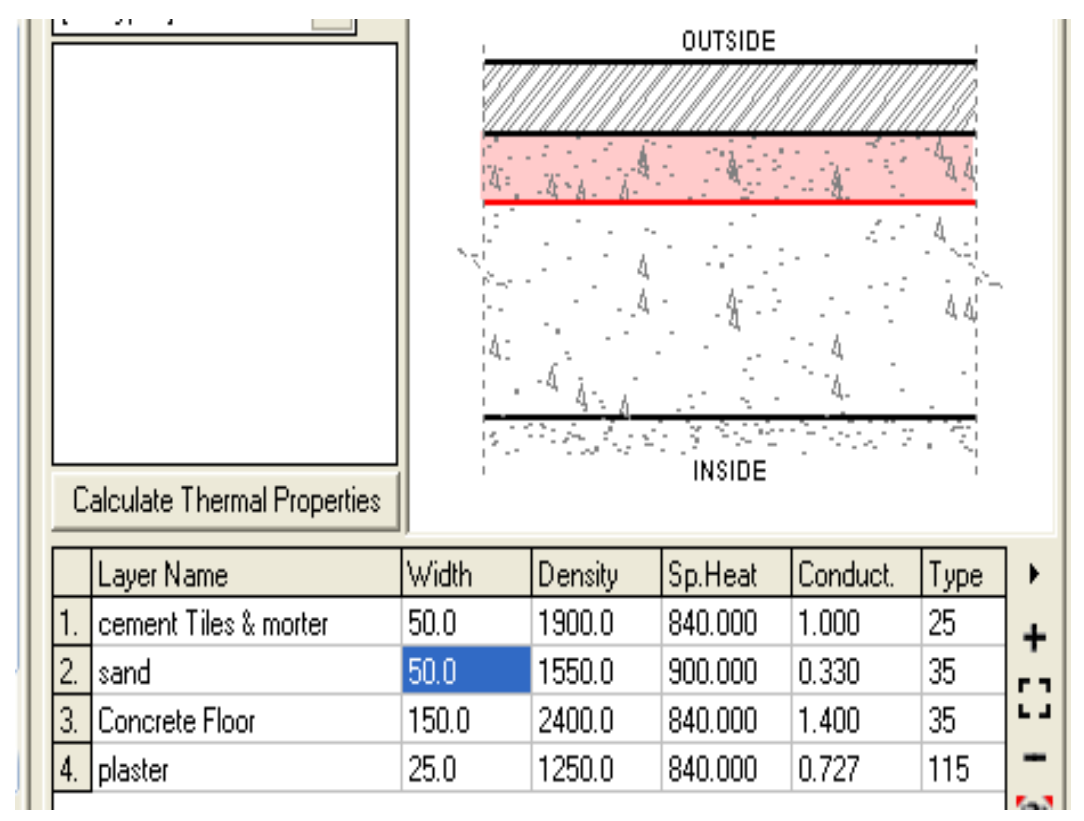

Fig. (5): A cross section in the roof with the thermo -physical properties. 


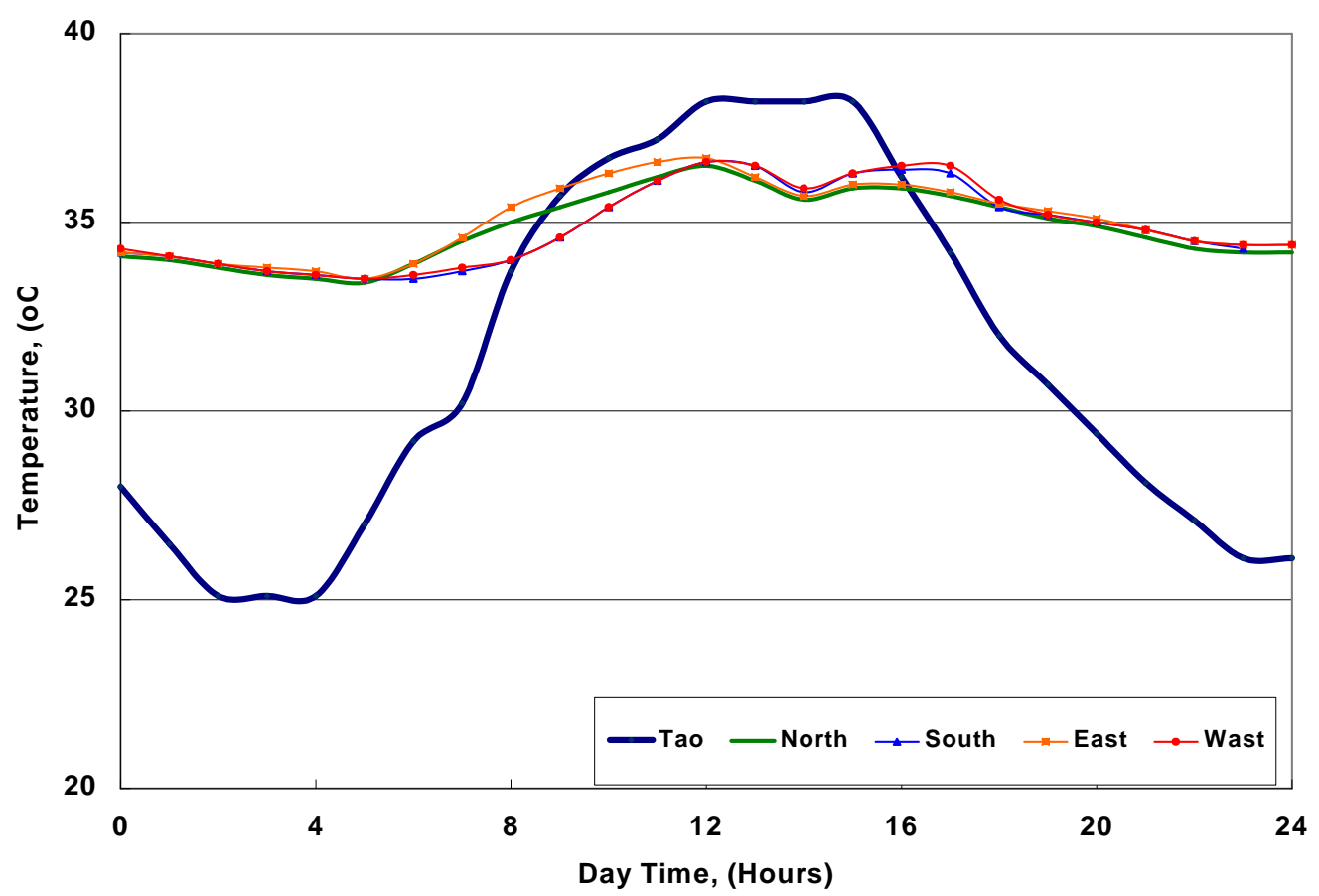

Fig. (7) : The hourly distribution of the outdoor air temperatures and the hourly estimated environmental indoor temperat ures inside the reception room in East El-Owauinat on July 21 at different orientations.

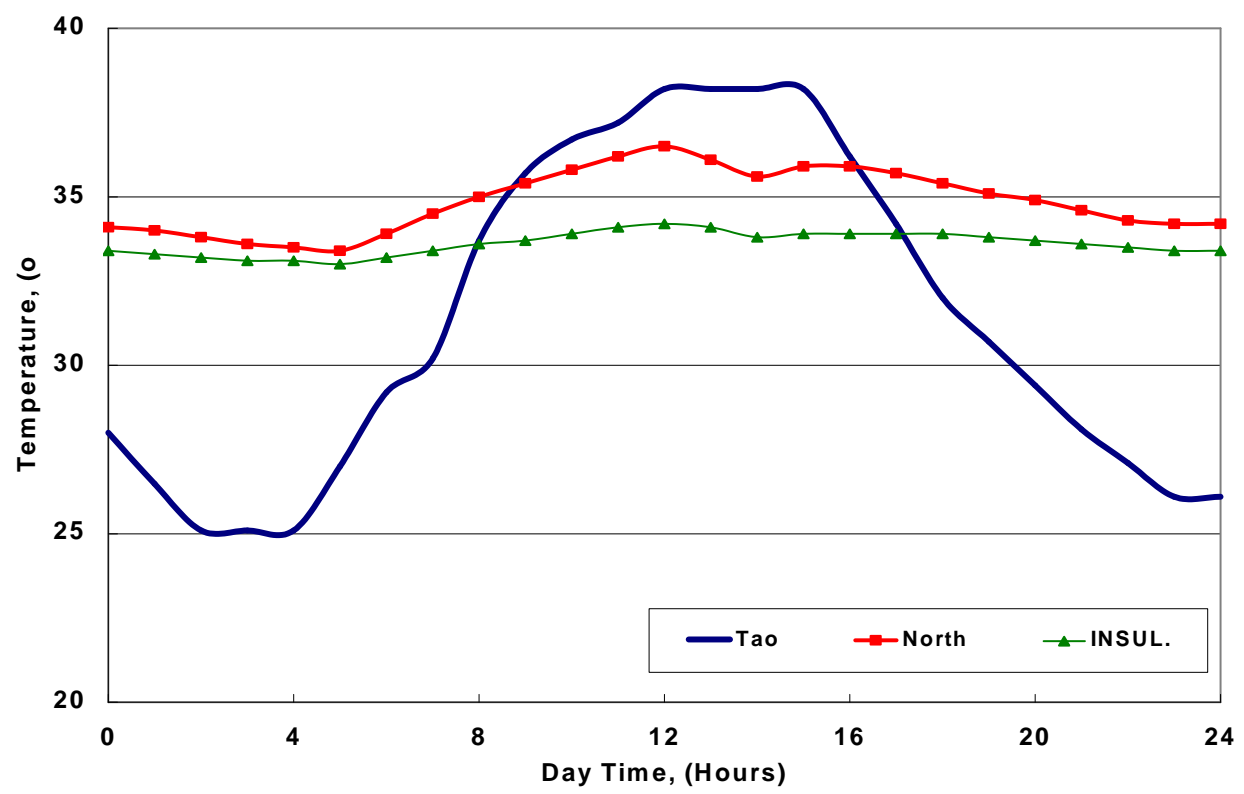

Fig. (8) : The hourly distribution of the outdoor air temperatures and the hourly estimated environmental indoor temperatures inside the reception room with/ without using thermal insulation in East El-Owauinate on July 21. 


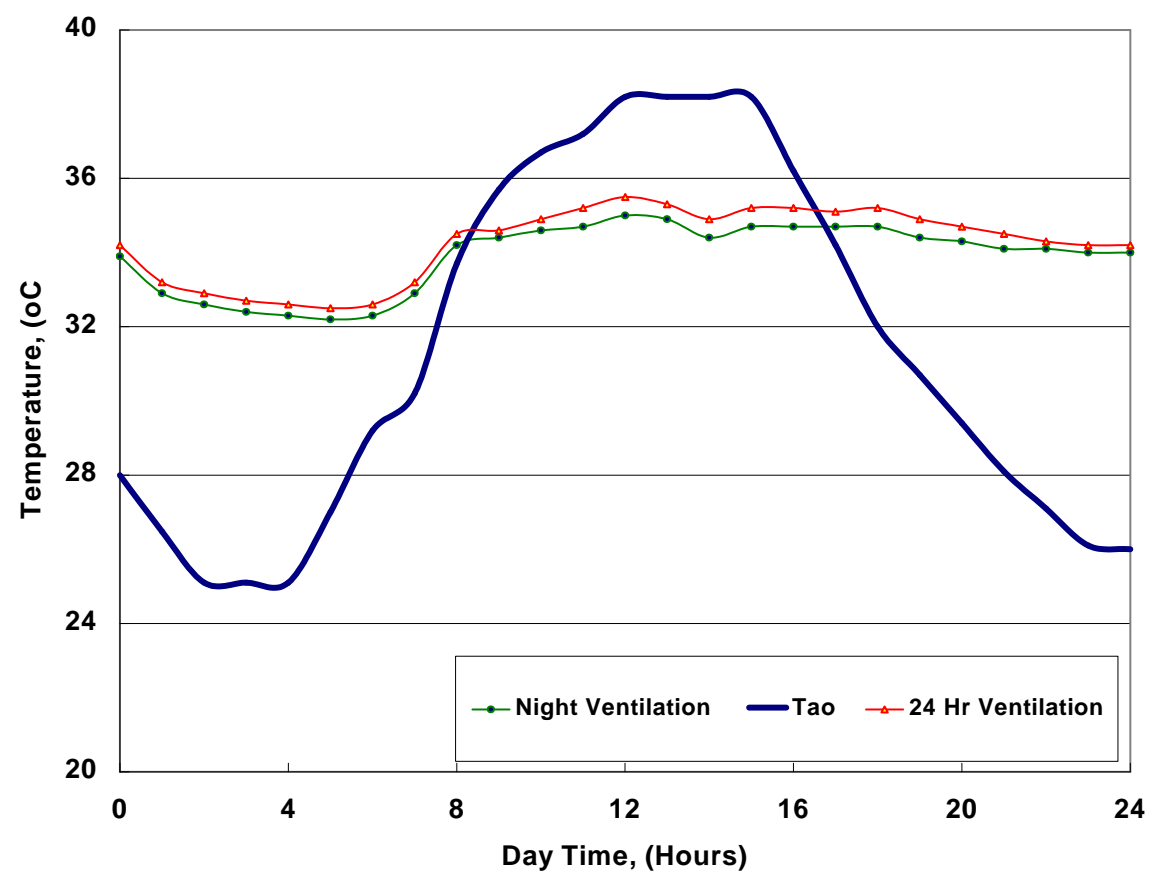

Fig. (9) : The hourly distribution of the outdoor air temperatures and the hourly estimated environmental indoor temper atures inside the reception room in East

El-Owauinate on July 21 at different ventilation period. 